\title{
Could tax compliance be increased? Measuring tax morale role in increasing tax compliance as a kind of strategy of sustainable future for human security from tax revenue
}

\author{
Abdul Rahman ${ }^{1}$ \\ $\frac{\left\{\text { rhnoke@gmail.com }{ }^{1}\right\}}{\text { STIA LAN Bandung }}{ }^{1}$
}

\begin{abstract}
Research regarding the tax reform worldwide proves the role of modern tax administration system (MTAS), tax sanction, tax service, and tax morale as elements of reform. Theoretically, tax compliance is influenced by economic and non-economic factors, in which, in the end, these factors lead to the same point with these elements. It means that the spirit of tax reforms worldwide is undertaken to improve tax compliance and to prevent tax noncompliance. The non-compliance is a major problem of countries imposing taxes on their society. It may be true that tax morale is an important factor behind this problem. Therefore, I am interested in measuring the tax morale role as a mediator in improving tax compliance. Study conducted in Indonesia toward 400 taxpayers who are employed in the public sectors through a survey method with a questionnaire as a tool to collect data. As a result, the existence of tax morale succeeded to increase the effect of MTAS on tax compliance. This study revealed the important role of tax morale as a mediator in enhancing tax compliance. This study recommends that the programs to increase tax compliance should be started from the tax morale. This is because improvements in this side will facilitate the government in achieving voluntary compliance in paying taxes so that a sustainable future for human security from the tax sector can be attained.
\end{abstract}

Keywords: tax compliance, MTAS, tax sanction, tax service, tax morale, sustainable future, human security

\section{Introduction}

Tax reform is a basic improvement of all tax aspects to obtain a good tax system, in which equity (fairness in the distribution of the tax burden), efficiency (economy in tax collection so as to have the lowest possible cost over and above the revenue that is raised), and simplicity (the tax system should be easy to understand and simple to comply with) occurs [1]. A good tax system raises the revenue needed to finance government activities without imposing unnecessary costs on the economy. Tax reform is about how revenue is raised, not just about how much. This is because tax reform offers one of the biggest opportunities to improve productivity and foster jobs, growth and opportunities. Theoretically, improvements expected through tax reform are namely modernizing tax administration, formulating transparent and stable tax laws by involving all stakeholders, conducting law enforcement, enhancing 
government credibility by using tax for public interest, and having political will and commitment in formulating and implementing tax reform [2]. The success of implementing a tax reform depends on the structure of tax system and the ability of tax administration to collect the expected tax revenues [3].

Tax reform movements in worldwide (transition, developed, and developing countries) arise as reaction of public trust to government in the 1960s and 1970s, development of modern concepts of public administration, inflation and finance deficit including the existence of international organization pressure such as World Bank and IMF to grow performance and liberalization economy and to improve tax administrative system [2]. In general, elements of tax reforms cover modernizing tax administration system by using appropriate IT systems for managing tax collection and for the anti-fraud operations, improving tax sanction to find a good balance between preventive measures that promote voluntary compliance and corrective measure and to fight against tax fraud and tax evasion, improving services to taxpayers, and tax morale by developing a relationship of trust between a government and its taxpayers including the strengthening of social norms. As result, tax reforms succeed to increase tax revenue and to improve the capability of a country to collect taxes or tax ratio with the interval 18 until 40 percent [4], [5].

In the same period, Indonesia also conducts tax reforms initiated because of increasing demand for more simple taxation and the necessity of income to finance developments and government operations. Tax reforms are performed in the two phases, in which the first stage is carried out in the interval of 1983 until 2000 by issued the policy to change official assessment with self-assessment, as a system that gives trust to the taxpayer to calculate, report and pay their own tax obligations. Afterward, the reforms are continued by innovations covered formulating a set of more simplicity, neutral, equity and certainty tax regulations, reorganization, enhancing of employee numbers and enlargement of the line procedures. Furthermore, the second phase of reform is began in 2001 by many innovations focused on modernizing tax administration system, improving tax sanction, tax service, and tax morale. Similar with result of tax reforms in the worldwide, both tax reforms also succeed to enhance tax revenue. However, the success story of Indonesia's tax reforms to increase tax revenue is not followed by the success in ability to collect taxes [6]-[10].

In general, the capability of a country to collect taxes is shown by tax ratio or comparison between tax revenue and Gross Domestic Product (GDP). Tax ratio also reflects the level of tax compliance in a country. In fact, in Indonesia, innovations that have performed through first and second phase of tax reforms only provide the tax ratio at around 12 percent until 2012. This ratio is lower than the international standard of tax ratio at about 19-25 percent for developing countries (under and upper-middle countries) and at around 35 percent for developed countries. In addition, by this ratio, Indonesia also exists below the standard for lower income countries (poor countries) which reached 14.3 percent [11].

Furthermore, if we compare Indonesia's tax ratio with the countries around it, the tax ratio is featured lower than other ASEAN5 countries [12]. The low tax ratio is caused by the low ratio of tax compliance. It is proved by an average of ratio of compliance at around 39 percent until 2012, It means that Indonesia has lost the potency of revenue about 60 percent since tax reform carried out in 1983 [13], [14]. The problematic tax compliance arise an assumption that there is a problem with tax morale of employees in public sectors as a representation of government. They could not provide 'role' as a role model in obeying tax laws and fulfilling tax obligations. This assumption is supported by the occurrences of tax corruption and tax collusion in Indonesia. 
Therefore, this study is focused on tax morale and the role of tax morale regarding tax compliance of employees in public sectors. As a representative of the government, the positive and negative behavior of them will influence the behavior of tax compliance of society in general. This is because, currently, Indonesia still adopts a paternalistic concept, in which the government is figuratively like a father and becomes a role model for the community in carrying out regulations including tax obligations [15]. Based on social learning theory and social cognitive theory [16] a role model behavior can affect the behavior of other people. With a study toward employees in the public sectors, expectedly, the linkage information between the compliance and role of a role model could be obtained.Tax morale is an intrinsic motivation of taxpayers in fulfilling their tax obligation. The existence of tax morale as an internal factor, surely, has an important role in influencing the behavior of tax compliance. On other hand, there are external factors affecting tax compliance such as applying modern tax administration system, tax sanction, and tax service. This paper endeavors to reveal the role of tax morale between direct effects of these elements on the tax compliance. In this context, the research question is "How is the role of tax morale of employees in public sectors toward tax compliance?" Furthermore, the following sub-research questions are derived from the main research question: What are the perceptions of taxpayers employed in public sectors regarding tax morale? And What is the role of tax morale as a mediator between the effect of modern tax administration system, tax sanction, and tax service on the tax compliance?

\subsection{Content of the relationship between a modern tax administration system and tax compliance}

The voluntary tax compliance becomes the main purpose of applying modern tax administration system [17]. Empirical studies prove that modern tax administration system, as a part of tax administration reform, has a relationship with tax compliance. In general, research related about it was made by Dr. Chaizi Nasucha, 2004 [7] that specializes in research on tax administration reform in Indonesia and examines its impact on taxpayer compliance. The results are: 1) reform of tax administration affects overall organizational accountability of directorate general of taxes; 2) the purpose of the tax administration reform is the increasing the taxpayer compliance. Reform of tax administration has a major impact on the taxpayer compliance; 3 ) accountability of the organization as part of a reform of the tax administration provides considerable influence on the taxpayer compliance; 4) reform of tax administration along with the accountability of tax organization has enormous impact on taxpayer compliance.

In specific, studies, which focused more on the relationship between the implementation of modern tax administration system and the tax compliance, are conducted by Sofyan, 2005 [18], Madewing, 2013 [19]. As a result, each research provides both a positive and significant effect between the modern tax administration system and the tax compliance. A meta-analysis study towards these researches also generates a similar result that there is a relationship between the modern tax administration system and tax compliance by $\rho=0.5294$; both the 0.0641 and 0.9947 confidence intervals (credibility of 95 percent). The difference of variation in relationships is because of an error in the sampling at 19.46 percent and error in the measurement at 4.69 percent.

\subsection{Content of relationship between tax sanction and tax compliance}

The existence of tax penalty is also expected to enhance compliance in reporting taxes [20]. In their implementations, tax sanctions are imposed for taxpayers conducting 
intentionally and unintentionally irregularities such as mistakes and delays in paying and submitting annual tax return, tax evasion, and tax avoidance. Commonly, taxpayers will obey when imposing tax sanction provide more loss for their incomes. This is consistent with the research from Bida (2001), in which the tax payment will be undertaken if the tax penalties can be regarded as a force to coerce taxpayers to comply with the laws and tax regulations. In the different insight, the public will pay taxes when tax penalties are implemented fairly, logically, consistently and can reach out to the offenders. Cuccia (1994) also concludes that the increase of fines to be paid taxpayers (both CPAs and non-CPAs) has an influence on the aggressiveness of taxpayers to meet their tax obligations. Therefore, the attitude and outlook of taxpayers toward tax sanction will affect the level of their tax compliance [21]. This is evidenced by research conducted by Witte and Woodbury (1985) and Trivedi et.al (2003), in which resulted that the biggest motivation in tax compliance is determined by the tax sanction.

\subsection{Content of relationship between tax service and tax compliance}

The existence of increasing satisfactory service to the taxpayer is expected to create comfort and easiness in fulfilling tax obligations [22]. Organization of economic cooperation developed countries (OECD) also states that the services to taxpayers by providing fair tax treatment and efficient would encourage taxpayer compliance rate. Conversely, the lack of interaction in the service leads to a lack of motivation to pay taxes [23]. Therefore the best services provided will affect taxpayer compliance. Regarding MortinerCaplin, voluntary compliance will be achieved when taxpayers are treated fairly and impartially [23]. Some studies show that voluntary compliance increases when the tax administrator provide better services (Wallschutzky, 1984). Study from Bird \& de Jantscher (1992) clarify that the readiness of tax officials is required in order to attain the high tax compliance [24]. Improvement in tax service creates the comfort and easiness in fulfilling tax obligations and encouraging taxpayer satisfaction [22]. This is evidenced by Supadmi [25] and Singh [26] in their studies indicating that the more satisfied taxpayers, the more taxpayer will comply with tax obligations. Leaderman (2003) by his study entitled tax compliance and the reformed IRS also stated that a tax authority focused on tax service will succeed effectively to increase tax compliance. Based on the research, he suggest to maintenance deeply taxpayers as a focus of services.

\subsection{Content of the relationship between tax morale and tax compliance}

Tax morale is moral principles or values held by individuals in realizing tax obligations or it can be said as intrinsic motivation to pay taxes. There is a significant relationship between taxpayer compliance with tax culture and tax morale in a country. It indicates the existence of influence of values, social norms and attitudes to the implementation of taxation in a country. In other word, cultural differences and tax morale determine the attitude of individuals to pay taxes. Therefore, tax morale differs systematically and significantly across countries (EU Report, 2012). In general, the research associated with the relationship between tax morale and tax compliance is carried out by James Alm and Benno Torgler in 2006. The result of study clarifies an existence of significant effect between them in the country. It means that there are influence of values, social norms and attitudes toward the implementation of taxation in a country. This research also highlights factors affecting tax morale involving perception of fairness toward the government's treatment to taxpayers (fair or not); trust toward government institutions; characteristic of the fiscal exchange between taxpayers and government including how do government services in the exchange process; and government awards to taxpayers 
such as giving fully the trust to taxpayers to calculate, to pay and to report their taxes (selfassessment) including rewards to honest taxpayers (reward and punishment system).

\subsection{Perception}

Wagner and Hollenbeck [27] stated that perception is the process by which individuals select, organize, store and interpret the information gathered from the sense of sight, hearing, touch, smell and taste. Furthermore, Robbins [28] defines the perception as a process reached individuals to organize and to interpret their sensory impressions to give meaning for their environment. He said that factors influencing perception consist of the perpetrator's perception, object or target perceived and situations. In the side of perpetrator's perception, the attitude, motives, interests, past experience and expectations become the important aspect. Furthermore, the object or target may be a person, object or event. The characteristics of an object or target usually affect the perception developed. In addition, the situation includes element of environment and time.

From these definitions, perception leads to: 1) visual perception obtained from the sense of sight. Visual perception is the result of what we see, both before (still imagine) and after, toward the object; 2) auditory perception gained from the sense of hearing (the ear); 3 ) the perception of touch taken from the skin; 4) The olfactory perception derived from the sense of smell (the nose); and 5) the perception of taste or flavor obtained from sensory of taste (the tongue). In this study, the perception is focused on the visual and auditory perception.

Theoretically, a perception influences individually a behavior [12]. The perception affects significantly behavior of consumer [29]. In the side of taxation, the existence of taxpayer perception that current tax administration system is more effective and easier in fulfilling tax obligations, will increase the willingness to pay taxes. The research regarding the effect of perception on tax compliance is conducted by Cummings (2004) toward two countries in Africa, namely Botswana and South of Africa. As a result, the perception of society toward the clean and fair government increases the level of compliance in submitting the annual tax return in Bostswana.

\section{Methodology}

This study applies the quantitative method, as a method of research that is based on the philosophy of positivism, is used to examine the population or a particular sample, data collection using research instruments, and quantitative data analysis for statistics, with the aim to test the hypothesis that has been set Sugiyono [30]. The quantitative research method is also an attempt to gather information from respondents, who are sampled using a questionnaire. This study intends to test a rational answer to explain the phenomenon becoming the research problem through describing the empirical facts, analyzing and clarifying the influence among variables.

In this study, objects of research consist of five variables, which are as follows: 1) modern tax administration system; 2) tax sanction; 3) tax morale; 4) tax service; and 5) tax compliance.

The object of research covers independent and dependent variable. The independent or exogenous variables in this study consist of 1) the modern tax administration system (X1), which covers four dimensions, namely modernizing structure, modernizing procedure, modernizing strategy, and modernizing culture based on the theory of Caiden [31]; 2) tax sanction (X2) with two dimensions both the criminal and administrative sanction; 3) tax service (X3) involving five dimensions, namely tangibles (physical evidence), reliability, 
responsiveness, assurance (security), and empathy based on the theory Zeithaml et al (1990); and 4) tax morale (X4) including three dimensions namely tax knowledge, tax fairness, and trust on government. Furthermore, dependent or endogenous variable is the tax compliance (Y), which consists of 4 dimensions, namely registering compliance, filling compliance, payment compliance, and reporting compliance.

Furthermore, this research has the typology of causality, which means that we will carry out testing of causality in the research by using the quantitative research to explain how the independent variables affect the dependent variable [32]. The framework is formulated based on the theory of planned behavior from Ajzen [10], in which that compliance behavior is influenced by control belief, behavior belief, and normative belief. In this context, tax sanction represents the control belief; tax morale represents the behavior belief; and then modern tax administration system and tax service represent the normative belief. Furthermore, the model also is arranged appropriate with elements of tax reforms and factors influencing tax compliance that, at least, cover: 1) aspect of tax administration; 2) aspect of tax sanction ; 3) aspect of tax service ; and 4) aspect of tax morale. The illustration of framework can be shown in the following figure:

Figure 1. Framework of study

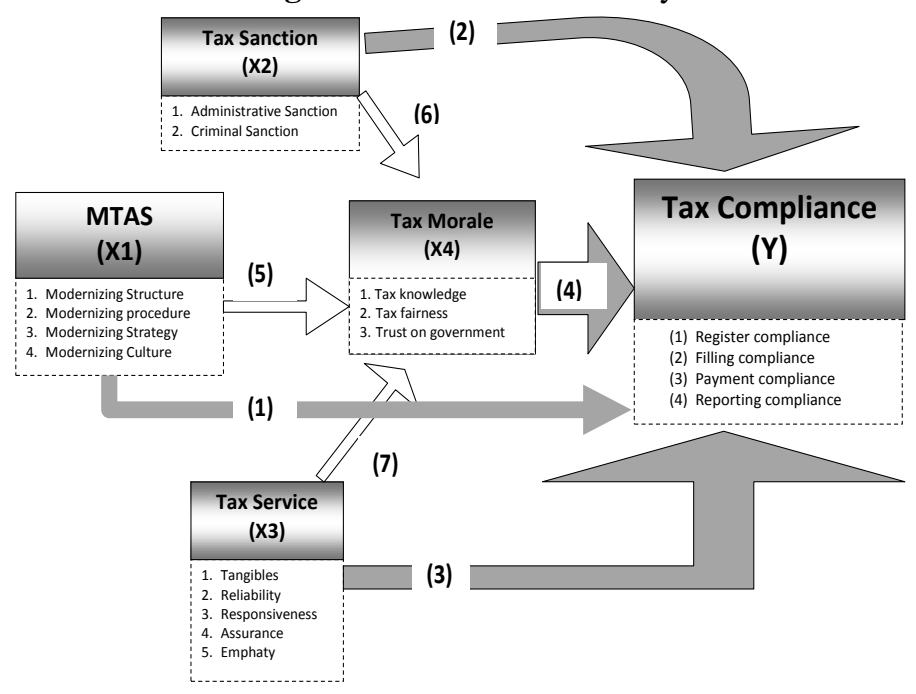

This framework will guide us in obtain the perceptions and their direct effects of both partial (one by one) and combined relationship from modern tax administration system (MTAS), tax sanction, tax service, \& tax morale as independent variables and tax compliance as the dependent variable.

According to figure 1, the patterns of direct effect in the side of partial relationship involve:

1. MTAS to tax compliance [ (1) ---> (Y)]

2. Tax sanction to tax compliance $[(2)--->(Y)]$

3. Tax service to tax compliance [ (3) ---> (Y) ]

4. Tax morale to tax compliance [ (4) ---> (Y) ]

Then, the pattern of direct effect in the side of combined relationship between MTAS, tax sanction, tax service, \& tax morale and tax compliance is: 
$[(1)+(2)+(3)+(4)--->(Y)]$.

On the other hand, we also can measure the indirect effect of MTAS, tax sanction, and tax service through tax morale on the tax compliance by the patterns as elaborated follow:

1. MTAS to tax compliance via tax morale [ (5) ---> (4) --- > (Y) ]

2. Tax sanction to tax compliance via tax morale [ (6) $--->(4)--->(Y)$ ]

3. Tax service to tax compliance via tax morale [ (7) ---> (4) --- > (Y) ]

In this study, we focus on indirect effect to obtain insight about the role of tax morale as a mediator to improve tax compliance.

The hypothesis is a provisional estimate about something that should be verifiable [30]. The form of hypothesis used in this study is a hypothesis associative. This is because this study explores the relationship between independent variables and the dependent variable. The hypotheses formulated then are be verifiable by using a series of statistical test. In this context, there are two kinds of statistical hypothesis involving the null hypothesis (H0) formulated to be rejected and the alternative hypothesis ( $\mathrm{Ha}$ ) determined to be accepted.

Figure 1 illustrates the framework study. Regarding this figure and by considering the taxpayers employed in public sectors as a unit analysis, we then hypothesize that:H1 :Indirect effect of modern tax administration system, tax sanction, and tax service through tax morale is higher than direct effect of these elements without tax morale on the tax compliance. Test of hypothesis is conducted by several steps, as can be elaborated as follow: (1) Determining a statistical hypothesis that refers to zero hypothesis formulated to be rejected and alternative hypothesis formulated to be accepted, (2) Conducting combined significant test (Test-F) to examine the hypothesis regarding the existence of combined effect from the independent variables to the dependent variable. The answer of this test is stated by statement that if the calculation of result $\mathrm{F}$ (F-count) is greater than value of $\mathrm{F}$ according to the table (F-table), then $\mathrm{Ho}$ is rejected and $\mathrm{Ha}$ accepted that means there is a combined effect from independent variables to the dependent variable. (3) Carrying out the partial significant test (t-test) to examine the hypothesis related to the existence of partial effect from the each independent variable to the dependent variable. The answer of this test is identified by the statement that if the value of the calculation of result $t$ ( $t$-count) is higher than the value of $t$ according to the table (t-Table), then we accept the alternative hypothesis (Ha), which clarifies that an individual independent variable affects the dependent variable. Furthermore is vice versa. In the implementation, the hypothesis testing is embodied by using regression analysis with the application of SPSS ver.17.0.

\section{Result and Discussion}

The results of this study reveal that most of the respondents are male, educated scholar, married, and aged between 29 till 39 years, who receive tax knowledge from the internet, tax dissemination, manual book of annual tax return and tax training, In addition, they also obtain knowledge from tax lesson materials, books, advertisement in television, information from the financial section, office, tax office, tax magazines, electronic media, mass media, and colleagues.

Regarding with the origin of respondents, this study notes that the respondents derive from 29 provinces either from the west or east Indonesia, in which the most of them are civil servant in local and center of government including army/police and state enterprise employees. Most respondents receive incomes beside salary from functional or structural allowance and honorarium from internal activities. The rest derived from teaching, speakers at 
a seminar or course, be an employee in private company, a consultant to other institutions and trading.

\section{A.The perceptions of taxpayers employed in public sectors regarding tax morale}

The perception of respondents on dimensions of tax morale based on score interpretation of $20.00-36.00=$ "very bad"; $36.01-52.00$ = "bad"; $52.01-68.00=$ "sufficient"; 68.01$84.00=$ "good"; "84.01 - 100.00 = "very good", can be presented in the following table:

Figure 2. Perception of respondent on dimensions of tax morale

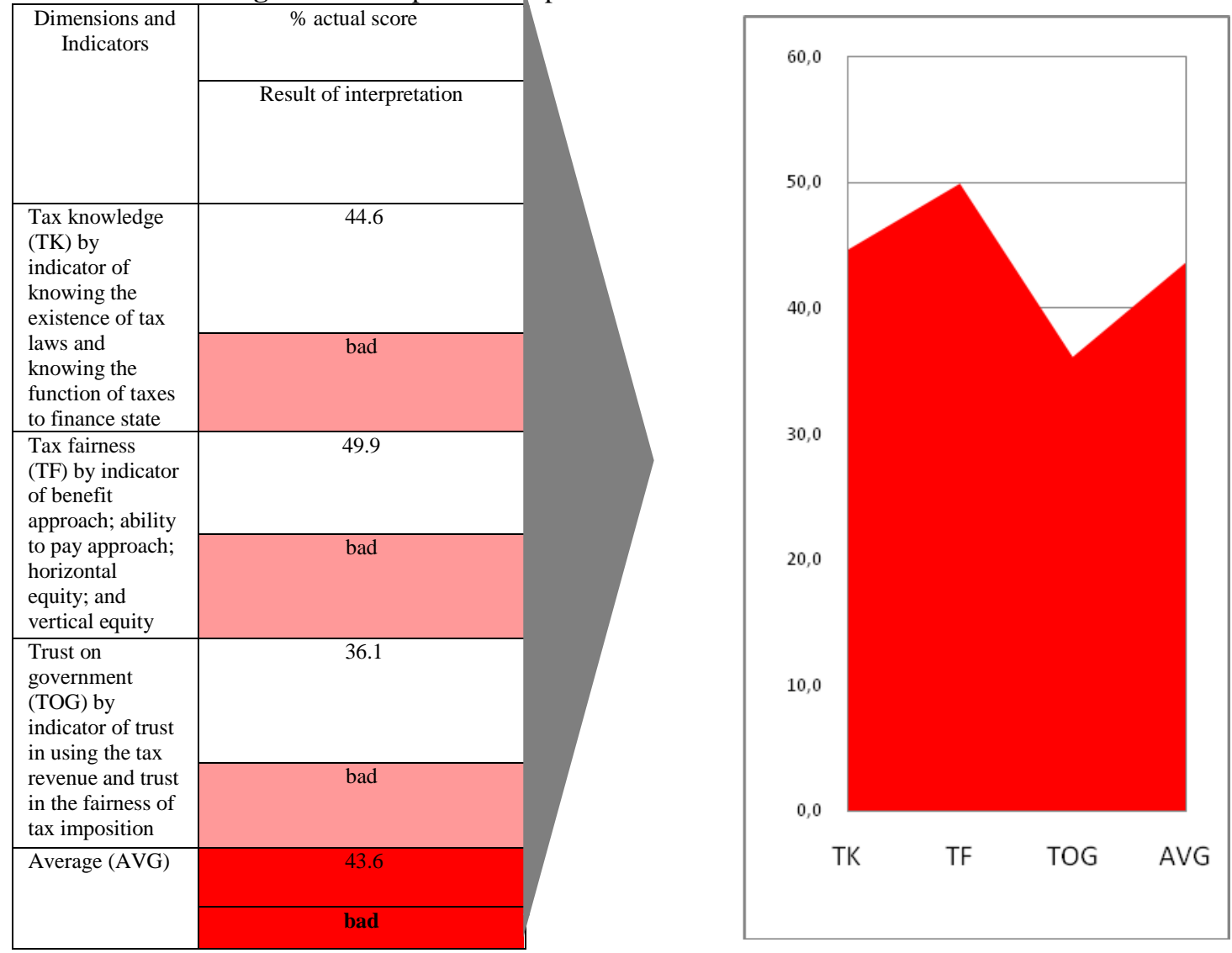

Based on the figure 2 the study finds that the perception of respondents on dimension of tax knowledge, tax fairness, and trust on government is bad. Overall, the average of perception is bad. This result indicates the existence of role model problem in tax morale.

B. Role of tax morale as a mediator between the effect of modern tax administration system, tax sanction, and tax service on the tax compliance 
The patern of relationship and direct effect of MTAS, tax sanction, tax morale, tax service on tax compliancecan be presented in the figure below:

Figure 3.patern of partial and combined effect of MTAS, tax sanction, tax morale, and tax service on tax compliance

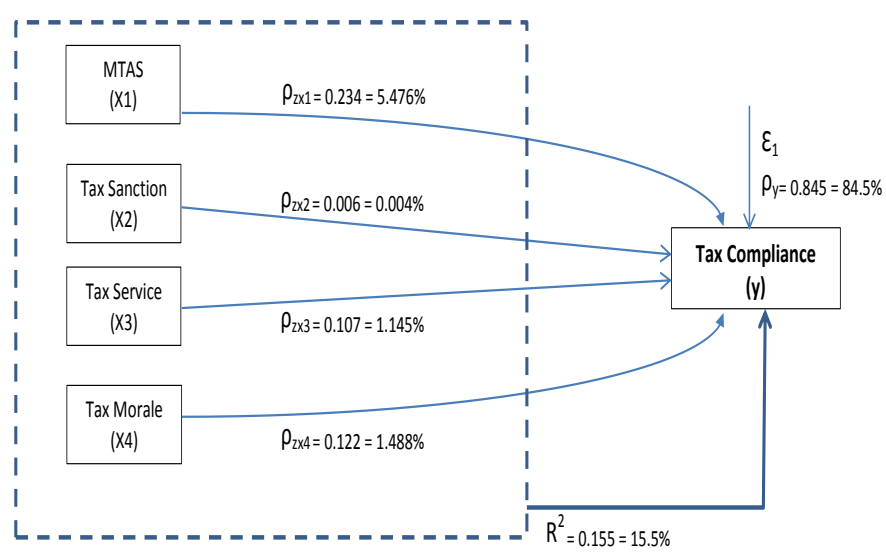

This study seeks and proves the role of tax morale as an important variable in improving tax compliance. We put the variable of tax morale as intervening or mediator variable between variable of MTAS, tax sanction, \& tax morale and tax compliance. With this scheme, then we measure the direct effect of MTAS, tax sanction, and tax service without tax morale to tax compliance. Afterward, we examine the indirect effect of these elements through tax morale on the tax compliance. This treatment is expected to know whether the existence of tax morale facilitates in increasing tax compliance among employees in public sectors, government employees, and state enterprise employees.

The pattern of relationship can be presented in the following figure:

Figure4. The patterns of direct and indirect effect between independent and dependent

variable

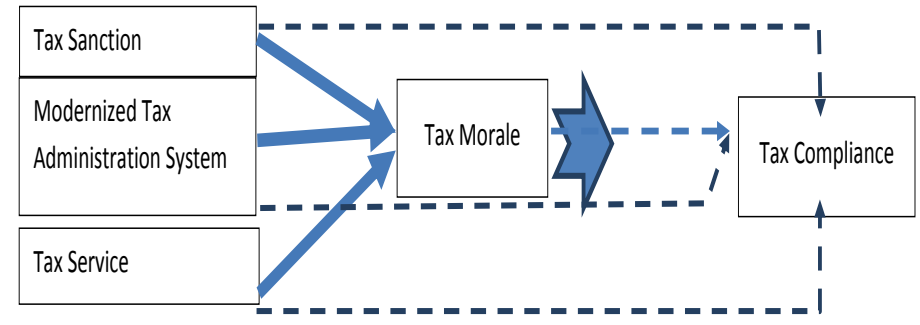

Referring figure 4, then, we measure the direct and indirect effect by using SPSS ver.17. In the side of employees in public sectors, the result can be shown in the following table:

Tabel 1. Summary of direct and indirect influence MTAS (X1), Tax Sanction (X2), Tax 
Service (X3), and Tax Morale (X4) on Tax Compliance (Y) of employees in public sectors.

\begin{tabular}{|c|c|c|c|c|}
\hline \multirow[b]{2}{*}{ Effect of variable } & \multicolumn{2}{|r|}{ Causal effect } & \multirow[b]{2}{*}{ Total } & \multirow{2}{*}{$\begin{array}{l}\begin{array}{c}\% \text { effect } \\
(\mathbf{R} \\
\text { square })\end{array} \\
\end{array}$} \\
\hline & Direct & $\begin{array}{l}\text { Indirect through } \\
\text { tax morale }(X 4)\end{array}$ & & \\
\hline \multirow{2}{*}{$\begin{array}{l}\text { MTAS (X1) on Tax } \\
\text { Compliance (Y) }\end{array}$} & 0,234 & & 0,234 & $5,476 \%$ \\
\hline & & $0,234+(0,264 \times 0,122)$ & 0,266 & $7,076 \%$ \\
\hline \multirow{2}{*}{$\begin{array}{l}\text { Tax Sanction (X2) } \\
\text { on Tax Compliance } \\
\text { (Y) }\end{array}$} & 0,006 & & 0,006 & $0,004 \%$ \\
\hline & & $0,006+(0,303 \times 0,122)$ & 0,043 & $0,185 \%$ \\
\hline \multirow{2}{*}{$\begin{array}{l}\text { Tax Service (X3) } \\
\text { on Tax Compliance } \\
\text { (Y) }\end{array}$} & 0,107 & & 0,107 & $1,145 \%$ \\
\hline & & $0,107+(0,272 \times 0,122)$ & 0,140 & $1,960 \%$ \\
\hline
\end{tabular}

Table 1.shows that the existence of tax morale succeed to increase the effect of MTAS on tax compliance at 1.6 percent, tax sanction at 0.181 percent, and tax service at 0.815 percent. Hence, this result clarifies that indirect effect of modernized tax administration system, tax sanction, and tax service through tax morale is higher than direct effect of these elements without tax morale on the tax compliance [hypothesis (H1) is accepted]. In this context, this study proves the important role of tax morale as a mediator in enhancing tax compliance of employees in public sectors.

\section{Conclusion}

This study highlights that employees in public sectors could not be able to fulfill their function as a role model for the society. This condition causes the perceptions of respondent regarding tax morale is bad. Therefore, the extraordinary efforts are required by focusing on tax morale. This is because tax morale succeeds to increase the effect of external factors influencing tax compliance such as modernized tax administration system, tax sanction, and tax service. In this context, this study reveals that indirect effect of modernized tax administration system, tax sanction, and tax service through tax morale is higher than direct effect of these elements without tax morale on the tax compliance.For the further study, we suggest to research regarding the effect of reward as a positive sanction and punishment as a negative sanction in order to increase the tax morale. By conducting this study, the results will be the basic input for the government to improve and to achieve voluntary tax compliance and surely for a better Indonesia.

\section{References}

[1] A. M. G. and A. Sandmo, "Income Tax Evasion: A Theoretical Analysis," J. Public Econ., vol. 1, no. 3/4, pp. 323-340, 1972.

[2] J. Alm, "A Perpective on The Experimental Analysis of Taxpayer Reporting," Account. Rev., vol. 66, no. 3, pp. 577-593, 1991.

[3] J. Alm, McClelland, G. H., Schulze, and W. D, "Why do people pay taxes?," J. Public Eco- nomics, vol. 48, pp. 21-48, 1992.

[4] J. Alm, I. Sanchez, and A. De Juan, "Economic and noneconomic factors in tax compliance," KYKLOS, vol. 48, pp. 3-18, 1995.

[5] J. Alm, "What is an 'optimal' tax system," Natl. Tax J., vol. 49, no. 1, pp. 117-133, 1996.

[6] J. Alm and B. Torgler, "Culture differences and tax morale in the United States and in 
Europe,” J. Econ. Psychol., vol. 27, no. 2, pp. 224-246, 2006.

[7] J. Andreoni, Erard, B., and Feinstein, “J Tax Compliance,” J. Econ. Lit., pp. 818-860, 1998.

[8] R. Aprilina, "Impact of Modern tax administration system on Tax Compliance Case Study: University of Brawijaya, Indonesia.” University of Brawijaya, 2012.

[9] A. Suharsimi, Research Procedure: an Approarch of Practice. Bandung: RinekaCipta, 2004.

[10] I. Ajzen, “The Theory of Planned Behavior, Organizational behavior dan Human Decision Process 50.” pp. 179-211, 1991.

[11] E. Babbie, Survey Research Methods, 2nd ed. Belmont, CA: Wordsworth, 1990.

[12] Bandura and Robbins, "Social Learniug Theory," in PerilakuOrganisasi :Konsep, Kontroversi, Aplikasi, Bahasa Ind., Jakarta: Prenhallindo, 1977.

[13] A. Berlianto, Tax Competition and Harmonization in Southeast Asia. New Zealand: Massey University, 2009.

[14] B. Bradley, The Fair Tax. New York: Pocket Books, 1984.

[15] J. Brondolo, C. Silvani, E. Le Borgne, and F. Bosch, "Tax Administration Reform and Fiscal Adjustment: The Case of Indonesia (2001-2007). Journal of Economics.,” 2008.

[16] R. E. Brown and M. M. J., "IRS's Comprehensive Approach to Compliance Measurement," Natl. Tax J., vol. 56, no. 3, 2003.

[17] R. Burgess and S. Nicholas, "Taxation and development," J. Econ. Lit., vol. 31, no. 2, pp. 762-830, 1993.

[18] "Caiden, Gearld E (1991). Administrative Reform Comes Of Ages, Berlin, New York, Walter TheGruyter, ppl 210-211."

[19] "Candra, Ricki, et.al (2013). Impact of Modern tax administration system on Tax Compliance. Case Study: Small Tax Office of Madiun, Indonesia. Journal of Research of Management and Accountancy, Vol.1, No.1."

[20] E. A. Posner, "Law and social norms: The case of tax compliance," Va. L. Rev., vol. 86 , p. 1781, 2000.

[21] A. N. Jatmiko, "Pengaruh Sikap Wajib Pajak pada Pelaksanaan Sanksi Denda, Pelayanan Fiskus dan Kesadaran Perpajakan terhadap Kepatuhan Wajib Pajak (Studi Empiris terhadap Wajib Pajak Orang Pribadi di Kota Semarang), P Program Pasca Sarjana Universitas Diponegoro, 2006.

[22] R. G. Cummings, J. Martinez-Vazquez, M. McKee, and B. Torgler, "Tax morale affects tax compliance: Evidence from surveys and an artefactual field experiment," $J$. Econ. Behav. Organ., vol. 70, no. 3, pp. 447-457, 2009.

[23] B. T. Camp, "Theory and practice in tax administration," Va. Tax Rev., vol. 29, p. 227, 2009.

[24] R. M. Bird and M. C. de Jantscher, Improving tax administration in developing countries, vol. 19. Washington DC: International Monetary Fund, 1992.

[25] N. L. SUPADMI and H. M. Jogiyanto, "Analisis hubungan antara Beta, ukuran perusahaan dan total risiko dengan return saham pada perusahaan manufaktur di Bursa Efek Jakarta," Universitas Gadjah Mada, 2003.

[26] V. Singh, "Tax simplification: The case of Malaysia," in The Complexity of Tax Simplification, London: Palgrave Macmillan, 2016, pp. 95-109.

[27] J. A. Wagner, J. R. Hollenbeck, and J. Russell, Management of organizational behavior. Prentice Hall, 1995.

[28] A. M. Kenny, B. Biskup, B. Robbins, G. Marcella, and J. A. Burleson, "Effects of vitamin D supplementation on strength, physical function, and health perception in 
older, community-dwelling men,” J. Am. Geriatr. Soc., vol. 51, no. 12, pp. 17621767, 2003.

[29] S. Yulianda and T. Handayani, "The effect of two aspects-quality products and consumers psychology-toward the purchase decisions of Samsung mobile phone," Mediterr. J. Soc. Sci., vol. 6, no. 5 S5, p. 203, 2015.

[30] Sugiyono, Metode Penelitian Pendidikan Pendekatan Kuantitatif, Kualitatif, $R$ dan D. Bandung: alfabeta, 2012.

[31] G. E. Caiden, "What really is public maladministration?," Indian J. Public Adm., vol. 37, no. 1, pp. 1-16, 1991.

[32] J. Creswell, Research Design, Qualitative, Quantitative, and Mixed Methods Approaches, III. California: SAGE, 2009. 